\title{
Hypersensitive Response-inducing Factor Secreted by Rice Blast Fungus on Suspension Cultured Cells of Rice
}

\author{
Kazunari NOMURA*, Katsuya SATO*,+, Shinji KAWASAKI** and Kenji ISHII* \\ *College of Bioresource Sciences, Nihon University, Fujisawa 252, Japan \\ ** National Institute of Agrobiological Resources, Tsukuba 305, Japan
}

Received 12 August 1996; accepted 14 January 1997

\begin{abstract}
Localized cell death and activation of phenylpropanoid metabolism in suspension-cultured rice cells are induced by factors secreted by blast fungus. Microscopic observation revealed that the death of cells at the periphery of calli appeared within $1 \mathrm{~h}$ after addition of a TCA-precipitable fraction (TCAp) of the fungus culture filtrate. The number of dead cells continued to increase for up to $24 \mathrm{~h}$, followed by general browning of the calli after about $48 \mathrm{~h}$. However, the culture still contained uninjured cells within the callus clumps, and there was no significant difference in culture viability from non-treated callus. Phenylalanine ammonialyase (PAL) and peroxidase (POX) activities were induced by TCAp and reached a maximum at $6 \mathrm{~h}$ and $\mathrm{1}^{-}$ 2 days after treatment, respectively. No cultivar-race specificity was found in PAL activity of cultured cells induced by TCAp. Phenolic compounds were found in callus tissue treated with TCAp. Among these phenolic compounds, accumulation of $p$-coumaric acid was remarkable. Fractions of fungal culture filtrate obtained by $\mathrm{C}_{18}$ reverse-phase chromatography were assayed for the ability to induce cell browning, PAL activity in cultured cells. Among the individual fractions, that which had the most potent activity to induce browning stimulated PAL activity.
\end{abstract}

\section{Introduction}

Higher plants defend themselves against microorganisms by various inducible mechanisms. The hypersensitive reaction (HR) is considered to be a generalized expression of plant resistance to pathogens. HR is characterized by rapid, localized necrosis of the infected tissue, and this is thought to restrict the spread of the pathogen [1]. Many metabolic changes associated with $\mathrm{HR}$, including phytoalexin production, accumulation of phenolic compounds, and hypersensitive cell death, are considered to play important roles in resistance to infection [2].

Previously suggested inducers of the hypersensitive response in various plants include cell wall preparations [3, 4], lipids [5], a small peptide [6], and glucan moiety of a glycoprotein [7]. The reactions of rice protoplasts to a crude fungal elicitor are very similar to the defence responses of rice leaf cells to infection by Pyricularia oryzae, since freshly prepared protoplasts completely retain their responsiveness to the crude fungal elicitor, finally resulting in defense gene activation. We have used such protoplasts to screen crude preparations of $P$. oryzae culture filtrate for active elicitors, and showed previously that heat- labile components are necessary for elicitor activity in rice [8].

In the present study, we report that treatment of rice cells cultured in liquid medium with the factor secreted by blast fungus induces localized cell death, and stimulates phenylpropanoid biosynthesis. Furthermore, the browning abilities were compared among preliminarily prepared fractions of the fungal culture filtrate to clarify the role of localized cell death in the induction of HR.

\section{Materials and Methods}

\section{1 Callus induction and suspension culture}

Near-isogenic lines derived from Nipponbare variety of rice (Oryza sativa L.) carrying + (Nipponba$r e+)$ was used in this experiment. The callus was induced from seeds on N6 medium [9] supplemented with $2 \mathrm{mg} / l$ 2, 4-D, $2 \mathrm{~g} / l$ casein hydrolysate, $3 \%$ sucrose and $0.8 \%$ agar at $26^{\circ} \mathrm{C}$. After one month, suspension cultures were obtained by transferring callus clumps to a liquid medium of the same composition. After the density of the callus suspension had increased, calli were subcultured every 10 days. Cultures 5-9 days after transfer were used for the experiment. 


\section{2 Preparation of crude fungal culture filtrates}

Pyricularia oryzae fungus strain Hoku 1 (race 007) was used. Crude culture filtrate was prepared according to the method by Nomura and Kawasaki (1992) [8]. Trichloroacetic acid (TCA) was added to $1 l$ of culture filtrate to make a $10 \%(\mathrm{w} / \mathrm{v})$ solution. After $3 \mathrm{~h}$ of incubation at $4^{\circ} \mathrm{C}$, the solution was centrifuged at 30 , $000 \times \mathrm{g}$ for $30 \mathrm{~min}$. The pellet was dissolved in distilled water followed by dialysis, lyophilization, and redissolved in $1 \mathrm{~m} l$ of distilled water.

\section{3 Reaction system}

Four milliliters of suspension-cultured rice cells (containing $4 / 15 \mathrm{~m} l$ packed cells) was transferred to a $20-\mathrm{m} l$ flask. The flasks were placed on a reciprocal shaker at 100 strokes/min. After $1 \mathrm{~h}$ of incubation, a sample of the blast fungal culture filtrate $(200 \mu l)$ was added to each flask. As a control, $200 \mu l$ of sterilized distilled water was added instead.

\section{4 Assay for cell death and culture viability}

Inability to exclude Evans blue dye was used as an indicator of cell death. To a $0.2-\mathrm{m} l$ sample of suspension cultured rice cells, $0.05 \mathrm{~m} l$ of Evans blue $(0.5 \%$ $(\mathrm{w} / \mathrm{v})$ in assay media) was added. Cells that stained dark blue were categorized as dead, and all other cells were considered viable. The percentage of dead cells was estimated by counting stained cells within five fields of view. The degree of cell death was evaluated using the equation: $(10 a+20 b+30 c+40 d) / N$, where $a$, $\mathrm{b}, \mathrm{c}$, and $\mathrm{d}$ are the number of cell clumps showing $20 \sim 40 \%, 40 \sim 60 \%, 60 \sim 80 \%$, of more than $80 \%$ of cells stained with Evans blue dye, respectively. $\mathrm{N}$ is the total number of observed cell clumps. The cell clumps showing $0 \sim 20 \%$ were estimated as viable.

Culture viability was assayed by a modification of the method of Buchell et al. [10]. Four $\mathrm{m} l$ of the cultured cells were incubated with $40 \mu l$ of fluorescein diacetate (FDA, Aldrich, Milwaukee) $(0.1 \mathrm{mg} / \mathrm{l}$ acetone) for $10 \mathrm{~min}$. The cells were washed twice with $\mathrm{N} 6$ medium by centrifugation and extracted with 3 $\mathrm{m} l$ of $85 \%$ methanol at room temperature for $30 \mathrm{~min}$. After centrifugation, the fluorescence of the supernatant was measured in spectrofluorometer using excitation and emission wavelengths of $375 \mathrm{~nm}$ and $520 \mathrm{~nm}$, respectively. The fluorescence intensity of the water-treated control in each experiment was defined as $100 \%$ viability, where the fluorescence of $85 \%$ methanol was $0 \%$.

\section{5 Partial purification of fungal culture filtrate}

The TCA precipitates (TCAp) of the culture filtrate were subjected to $C_{18}$ reverse-phase chromatography (TSK-Gel Octadecyl-4PW, $4.6 \times 150 \mathrm{~mm}$, TOSOH). After the column had been washed with $28 \%$ acetonitrile containing $0.01 \%$ TFA, $200 \mu l$ of TCAp was applied. Proteins were eluted with a linear gradient of $28-48 \%$ acetonitrile. Appropriate fractions were collected and lyophilized following dissolution in $200 \mu l$ of distilled water.

\section{6 Enzyme extraction and assays}

\subsubsection{PAL activity}

Cultures were homogenized in a mortar with $10 \mathrm{ml}$ of $0.1 \mathrm{M}$ borate buffer, $\mathrm{pH} 8.8$, containing $0.25 \% \mathrm{PVP}$ and $1 \mathrm{mM}$ DTT. The homogenate was centrifuged at $20,000 \times \mathrm{g}$ for $10 \mathrm{~min}$. and the supernatant was assayed immediately. The reaction mixture contained $200 \mu l$ of crude enzyme solution, $100 \mu l$ of $10 \mathrm{mM}$ phenylalanine and $700 \mu l$ of borate buffer at $\mathrm{pH} 8.8$. The mixture was incubated for $3 \mathrm{~h}$ at $40^{\circ} \mathrm{C}$, and the reaction was stopped by addition of $100 \mu l$ of $6 \mathrm{~N} \mathrm{HCl}$. After two extractions with $2 \mathrm{~m} l$ of ethyl ether, the combined ether phase was evaporated to dryness. The residue was dissolved in $1 \mathrm{~m} l$ of $0.05 \mathrm{~N} \mathrm{NaOH}$, and optical density at $268 \mathrm{~nm}$ was measured with a spectrophotometer. PAL activity was expressed as $\mu$ mole of $t$-cinnamic acid formed per $\mu \mathrm{g}$ protein in enzyme solution per $h$.

\subsection{POX activity}

One gram of the collected callus tissue was homogenized with $10 \mathrm{~m} l$ of $0.1 \mathrm{M}$ acetate buffer at $\mathrm{pH}$ 5.0 containing $0.25 \% \mathrm{PVP}$, and the homogenates were centrifuged at $20,000 \times \mathrm{g}$ for $10 \mathrm{~min}$. The supernatants were used as enzyme solutions. The reaction mixture, containing $0.2 \mathrm{~m} l$ of enzyme solution, $0.1 \mathrm{~m} l$ of $0.1 \%$ methoxyphenol, $0.1 \mathrm{~m} l$ of $0.1 \% \mathrm{H}_{2} \mathrm{O}_{2}$ and 2.6 $\mathrm{m} l$ of acetate buffer, $\mathrm{pH} 5.0$, was incubated at $30^{\circ} \mathrm{C}$. The increase in optical density at $420 \mathrm{~nm}$ was measured for $3 \mathrm{~min}$.

\section{7 Extraction and determination of phenolic compounds}

The cultured cells in a flask were homogenized in 2 $\mathrm{m} l$ of $80 \%$ methanol, and the homogenate was centrifuged at $12,000 \mathrm{rpm}$ for $10 \mathrm{~min}$. The precipitate was then re-extracted with $2 \mathrm{ml}$ of $80 \%$ methanol. The combined methanol extract was reduced to dryness in vacuo at $35^{\circ} \mathrm{C}$, and the residues were dissolved in methanol. HPLC was performed by $\mathrm{C}_{18}-\mathrm{RP}$ chromatography (TSK-Gel Octadecyl-4PW, $4.6 \times 150$ $\mathrm{mm}, \mathrm{TOSOH})$. The column was equibrate with $10 \%$ methanol in $2 \%$ acetic acid. Phenolic compounds were eluted by washing with $24 \mathrm{~m} l$ of a linear gradient of methanol $(10 \sim 35 \%)$.

\section{Results}

\section{1 Viability and death of cultured rice cells}

Microscopic observation revealed that cells at the 


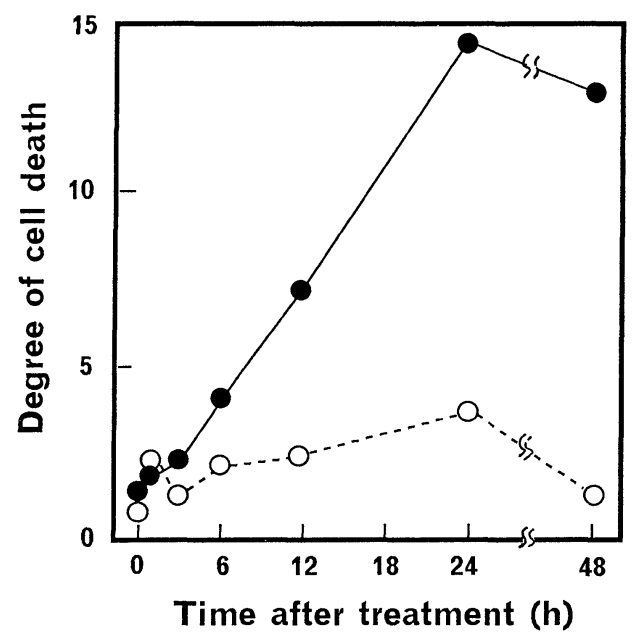

Fig. 1 Ability of the TCA-precipitable fraction (TCAp) from blast fungus to induce death of rice cultured cells, as assayed by Evans blue incorporation.

TCAp containing $1.6 \mathrm{mg}$ protein $(\mathbf{)}$ ) or distilled sterilized water $(\bigcirc)$ was added to each $4-\mathrm{m} l$ suspension culture.

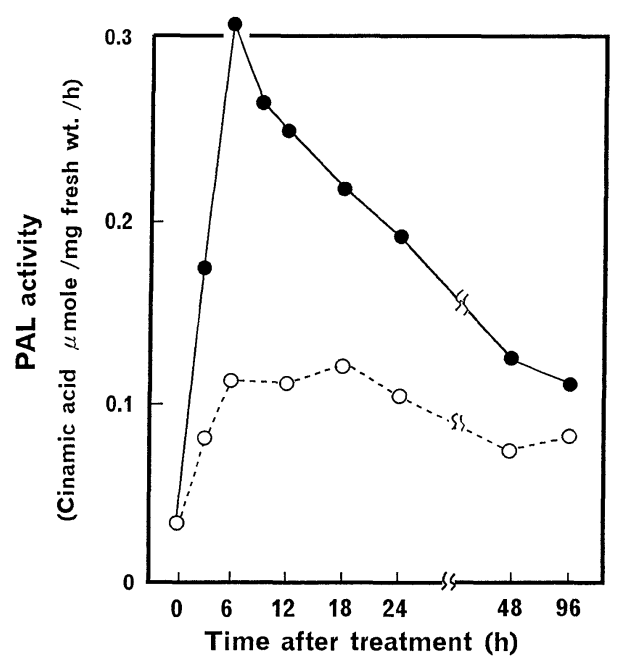

Fig. 3 PAL activity of cultured rice cells as a function of time of incubation after treatment with TCAp

(- ) or sterilized water $\left(\bigcirc^{--} \bigcirc\right)$.

periphery of the calli had begun to die. The dead cells started to appear within $1 \mathrm{~h}$ after TCAp addition as assayed by Evans blue incorporation, and the number of dead cells increased from about $3 \mathrm{~h}$ after the addition and continued to increase up to $24 \mathrm{~h}$ (Fig. 1). The callus growth treated with TCAp was slightly inhibited. There was no remarkable difference from non-treated callus in cell viability as assayed by FDA incorporation (Fig. 2). The treatment with TCAp resulted in a general brownish appearance of superficial cells of the calli after $48 \mathrm{~h}$. However, dry weight of treated callus increased after 2 days, suggesting that the culture still contained uninjured cells within the calli. TCAp induced this localized cell death within the range of the tested concentrations (100-800 $\mu$ g protein $/ \mathrm{m} l$ culture).

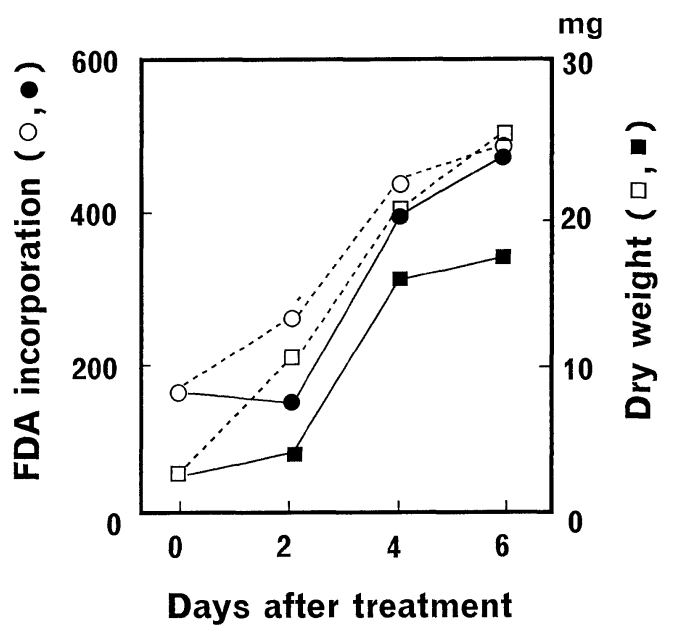

Fig. 2 Viability of cultured rice cells at various times after treatment with fractions of the TCA-precipitable (TCAp) fraction of culture filtrate of blast fungus.

Suspension cells were treated with sterilized water $(\bigcirc, \square)$ or TCAp

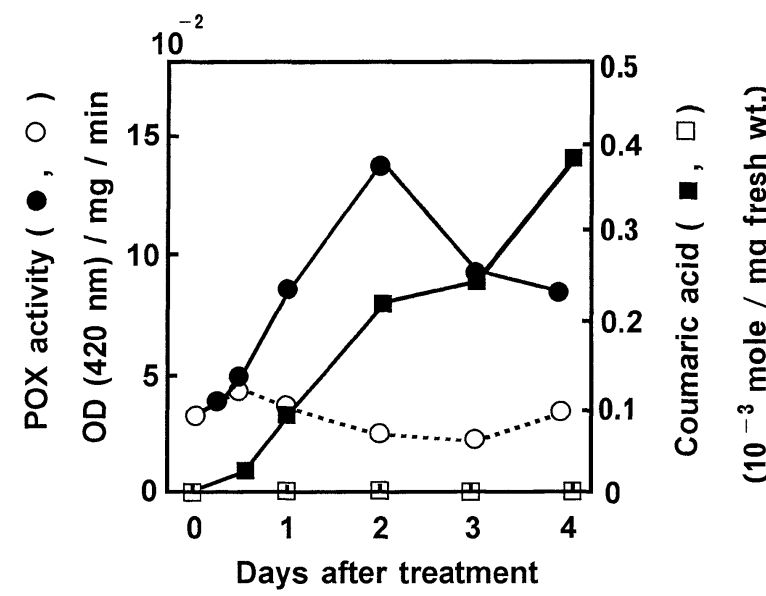

Fig. 4 Time course of the appearance of POX activity $(\bigcirc, \mathbf{O})$ and accumulation of coumaric acid $(\square, \mathbf{\square})$ after treatment of cultured rice cells with TCAp $(\boldsymbol{O}, \mathbf{\square})$ or sterilized water $(\bigcirc, \square)$ as controls.

\section{2 Activation of PAL and POX, and Accumulation of phenolic compounds}

Constitutive PAL activity at zero time was detected, and the activity of control cells treated with water continued to increase slightly until $18 \mathrm{~h}$. Elevated PAL activity was induced by TCAp $3 \mathrm{~h}$ after treatment and reached a maximum at $6 \mathrm{~h}$. After $6 \mathrm{~h}$, the activity was progressively reduced (Fig. 3).

Induction of POX activity was seen in response to TCAp, reaching a peak of activity 1 day after treatment and continuing until 2 days after treatment, followed by a reduction (Fig. 4). Browning of suspended cells appeared 2 days after treatment. Phenolic compounds were found in callus tissues 1 day after treatment and continued to increase until the $4 \mathrm{~h}$ day (Fig. 4). Chlorogenic acid, vanillic acid, ferulic acid, $t$ cinnamic acid and $p$-coumaric acid were all detect- 
Table 1.

Determination of phenolic compounds in cultured cells of

Nipponbare- + treated with TCAp from Hoku 1.

\begin{tabular}{ccccc}
\hline \multicolumn{5}{c}{ Phenolic compounds $\left(10^{-3}\right.$ mole/mg fresh wt. $)$} \\
\hline $\begin{array}{c}\text { Chlorogenic } \\
\text { acid }\end{array}$ & $\begin{array}{c}\text { Vanillic } \\
\text { acid }\end{array}$ & $\begin{array}{c}\text { Ferulic } \\
\text { acid }\end{array}$ & $\begin{array}{c}p \text {-Coumaric } \\
\text { acid }\end{array}$ & $\begin{array}{c}t \text {-Cinnamic } \\
\text { acid }\end{array}$ \\
\hline 0.330 & 0.125 & 0.151 & 0.772 & 0.062 \\
\hline
\end{tabular}

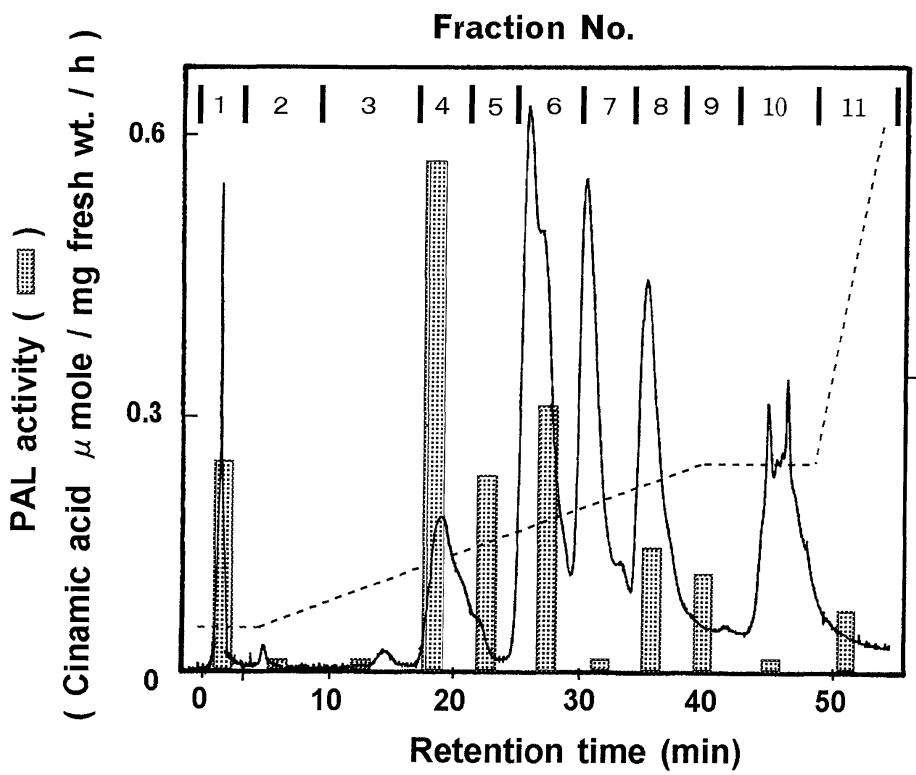

0.4

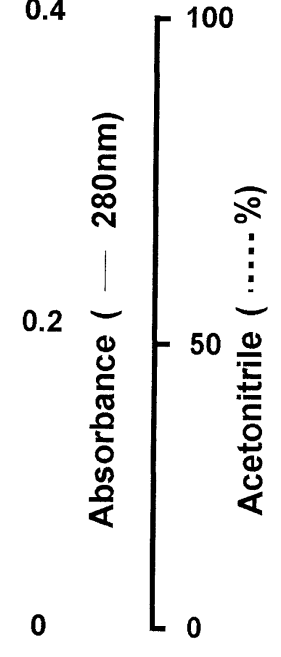

Fig. 5 Determination of PAL-inducing activity in cultured rice cells of fractions secreted by blast fungus partially by $\mathrm{C}_{18} \mathrm{RP}$ chromatography.

Suspension cultured rice cells of Nipponbare+ were treated with a sample of fungal culture filtrate of Hoku 1.

Table 2.

Effect of $\mathrm{C}_{18}$ fractions on the activity to induce discoloration of cultured rice cells.

\begin{tabular}{|c|c|c|c|c|c|c|c|c|c|c|}
\hline & \multicolumn{10}{|c|}{ Fraction number } \\
\hline & 1 & 2 & 3 & 4 & 5 & 6 & 7 & 8 & $9 \quad 10$ & 11 \\
\hline Discoloration & + & - & - & +++ & - & + & - & - & $+\quad+$ & - \\
\hline $\begin{array}{l}\text { The } 4-\mathrm{m} l \text { suspen } \\
\mathrm{n} l \text { RP fractions } \\
\text { he cells was ob } \\
\text { lightly brown; }\end{array}$ & & (1t & & $\begin{array}{l}\text { of Nipp } \\
\text { from TC } \\
\text { s after } \\
\text { ely brov }\end{array}$ & Ap & & & & $\begin{array}{l}\text { ated with } \\
\text { colorati } \\
\text { change } \\
\text { kably br }\end{array}$ & $\begin{array}{l}0.2 \\
\text { on o }\end{array}$ \\
\hline
\end{tabular}

able by RP chromatography. Among these phenolic compounds, accumulation of $p$-coumaric acid was remarkable, accounting for about $53.6 \%$ of the total phenol production (Table 1).

\section{3 Fractionation of fungal culture filtrate}

A characteristic protein profile monitored by absorbance at $280 \mathrm{~nm}$ from the RP column is shown in Fig. 5. Five major peaks were evident in the TCAp. Appropriate fractions were combined to the fractions $1 \sim 11$. The RP fractions were then assayed for their ability to induce PAL activity in callus cells $6 \mathrm{~h}$ after treatment. Among the individual fractions, fraction 4 had the highest PAL-inducing activity and exhibited a $3.5^{-}$ fold increase in specific activity as compared to the original TCAp. The RP fractions containing protein were assayed for their ability to induce browning of cultured cells 2 days after treatment (Table 2). Fraction 4 had the highest browning-inducing activity. The fraction was the same as the protoplast-disrupting fraction in Nomura et al. [11].

\section{Discussion}

It was demonstrated that Pyricularia oryzae secreted necrosis-inducing activity into the culture medium. 
The TCA-precipitable fraction (TCAp) in the culture filtrate of $P$. oryzae induced localized death and browning of suspension-cultured rice cells, although callus growth was only slightly inhibited and there was no significant difference from non-treated callus in cell viability. Masuda et al. [12] reported that addition of chitosan to exponentially growing rice suspension cultures within hours after transfer of the cells to new medium caused browning of cells and the growth medium within $24 \mathrm{~h}$.

It was shown that TCAp induced increases of PAL, POX, and accumulation of phenolic compounds as well as browning of the peripheral callus cells. PAL catalyzes the first reaction in the general pathway of the biosynthesis of phenylpropanoid compounds including flavonoids, cinnamate esters, and lignin. The activity of this enzyme is enhanced by various kinds of environmental stress such as wounding, light, and infection [13]. Uchiyama et al. [14] reported that PAL activity was increased in rice callus $24 \mathrm{~h}$ after inoculation with blast fungus, and that the quantity of polyphenols was slightly increased, whereas free $o$-diphenols were scarcely detected in both infected and non-infected rice callus cultures. In the present study, several phenolic compounds were found in callus tissues treated with TCAp. Among them, accumulation of $p$-coumaric acid was remarkable, suggesting that this was the main phenolic component induced by TCAp. Activation of phenylpropanoid metabolism is believed to result in phenolic polymer deposition, which builds up new mechanical barriers against pathogen invasion $[15,16]$. Hydroxycinnamic acids and their derivatives are thought to contribute to the discoloration of host tissues at the site of infection [17, 18]. It is necessary to elucidate which phenolic compound is related to resistance of rice to blast fungus.

The RP fractions were assayed for their ability to induce cell browning and PAL activity in callus cells. Among the individual fractions, fraction 4 had the most potent activity to induce cell browning, and the highest PAL-inducing activity. These results indicate that fraction 4 contains the activity to induce phenylpropanoid metabolism accompanied by localized cell death. Nomura and Kawasaki [8] reported that a concentrated culture filtrate of rice blast fungus showed strong activity to disrupt protoplasts of rice leaves. The protoplast-disrupting factor was precipitated with TCA and labile above $60^{\circ} \mathrm{C}$, suggesting that it is proteinaceous in nature. The heat-labile factor responsible for disrupting protoplasts was partially fractionated by reverse-phase chromatography. The active fraction was eluted with an acetonitrile gradient in the early phase [11]. Fraction 4 in this study responsible for inducing localized cell death in callus tissue was the same as the protoplast-disrupt- ing fraction (data not shown). The applying of fraction 4 on press-injured spots of rice leaves had no effect on inducing necrosis, however, press-injection of the fraction induced necrosis [19]. It is envisaged that the factor in TCAp affects the plasma membrane but not the cell wall directly, although the factor induces localized death of suspension-cultured cells because their cell walls may be looser than those of intact epidermal cells in leaves.

\section{References}

[1] Lamb, C.J., 1989. Cell, 56: 215-224.

[2] Tomiyama, K., 1982. In "Plant Infection: The Physiological and Biological Basis” (eds. by Asada, Y., et al.), p. 329-334, Jpn. Sci. Soc. Press, Springer-Verlag, Tokyo, Berlin.

[ 3 ] Doke, N., Tomiyama, K., 1980. Physiol. Plant Pathol., 16: 177-186.

[4] Currier, W. W., 1981. Trends Biochem. Sci., 6: 191-194.

[ 5 ] Preisig, C.L., Kuć, J.A., 1988. Physiol. Mol. Plant Pathol., 32: 77-88.

[6] De Wit, P.J.G.M., Hofman, A.E., Velthius, G.C. M., Kuć, J.A., 1985. Plant Physiol., 77: 642-647.

[7] Moerschbacher, B., Kogel, K.H., Noll, U., Reisener, H.J., 1986. Z. Naturforsch., 41c: $830-$ 838.

[8] Nomura, K., Kawasaki, S., 1992. Ann. Phytopathol. Soc. Jpn., 58: 200-207.

[9] Chu,C.-C., Wang, C.-C., Sun, C.-S., Hsu, C., Yin, K.-C., Chu, C.-Y., Bi, F.-Y., 1975. Scientica Sinica, 18: 659-668.

[10] Bucheli, P., Doares, S.H., Albersheim, P., Darvill, A., 1990. Physiol. Mol. Plant Pathol., 36: 159-173.

[11] Nomura, K., Kawasaki, S., Ishii, K., 1992. In "The Inpact of Biological Research on Agricultural Productivity" (eds. by Huang, S.C., et al.), p. 251-255, Taichung Dist. Agr. Imp. St.

[12] Masuda, C., Bulcke, M. Van den, Bauw, G., Montagu, M. Van, Caplan, A.B., 1991. Plant Physiol., 97: 619-629.

[13] Minami, E., Shibuya, N., Kuchitu, K., Tanaka, Y., Anndoh, I., Ohtsuki, Y., 1992. In "Molecular Biology and Biotechnology of Genes in Plant Pathogens and Their Hosts" (ed. by Motoyoshi, F.), p. 75-84, The Phytopath. Soc. Jpn.

[14] Uchiyama, T., Kato, H., Ito, M., Ogasawara, N., 1984. Ann. Phytopath. Soc. Jpn., 50: 176-188.

[15] Favali, M.A., Conti, G.C., Bassi, M., 1978. Physiol. Mol. Plant Pathol., 13: 247-251.

[16] Legrand, M., 1983. In "Biochemical Plant Pathology” (ed. by Callow, J.A.), p. 367-384, John Wiley \& Sons, Chichester, UK.

[17] Aist, J.R., Gold, R.E., Bayles, C.J., Morrison, G. H., Chandra, S., Israel, W., 1988. Physiol. Mol. 
Plant Pathol., 33: 17-32.

[18] Bolwell, G.P., Robbins, M.P., Dixon, R.A., 1985. Eur. J. Biochem., 148: 571-578.
[19] Nomura, K., Sakai, K., Kawasaki, S., Ishii, K., 1993. Jpn. J. Breed., 34(Suppl. 43): 225. 